\title{
Mervärdesmat, nyttomat eller mat med hälsopåståenden?
}

Debatten om vad functional foods skall heta på svenska går vidare. Mervärdesmat, som föreslagits av Svenska Språknämnden och Terminologicen trum, debatterades i denna tidskrift $\mathrm{nr} 2 / 01$ (1). $\mathrm{Nu}$ har Forskning och Framsteg redovisat sin ordtävling (2). Man valde ut 10 ord som kunde behöva svenska benämningar, bland dem functional food. Över 3300 personer röstade. Nyttomat fick $30 \%$ av rösterna, mervärdesmat bara 20\%. Smartmat (17\%) och funktionell mat (16\%) kom också före att behålla functional food $(7 \%)$.

Functional food har ingen officiell definition. I det stora EU-stödda projektet "Functional Food Science in Europe" enades forskare från akademin och industrin om en arbetsdefinition som kan översättas såhär: 'Ett livsmedel kan anses 'funktionellt' om det visats påverka en eller flera funktioner i kroppen gynnsamt, utöver normala funktioner av näringsämnen, på ett sätt som är relevant för förbättringar av hälsa och välbefinnande och/eller minskad risk för sjukdom. Functional foods är livsmedel, inte tabletter eller kapslar, och effekterna skall uppkomma vid konsumtion som en del av en normal kost." (3). Livsmedel som kvalificerar för "produktspecifika fysiologiska påståenden, PFP" enligt det utvidgade egenåtgärdsprogrammet (4) stämmer väl överens med denna definition. Det är fråga om produkter som genom vetenskapliga studier visats ha vissa hälsobefrämjande (och/eller prestationshöjande) effekter.

I praktiken har functional foods emellertid kommit att användas betydligt bredare som ett koncept eller paraplybegrep p för på olika sätt hälsomässigt optimerade livsmedel, oavsett om produkten testats i vetenskapliga studier eller ej. Berikade produkter (Plus-produkter), fiberrika produkter och produkter med modifierad fettsyrasammansättning är exempel på livsmedel som ofta kallas functional foods utan att uppfylla den ovan nämnda strikta definitionen. Med hänsyn till hur functional foodsbegreppet utvecklats och används på marknaden, är det knappast möjligt att nu snäva in begreppet till den egentliga definitionen. Det är knappast heller önskvärt. Låt oss istället fortsätta använda det som ett koncept eller paraply för produkter som utvecklats utifrån dagens snabbt växande kunskap om hälsomässiga effekter av livsmedel och livsmedelskomponenter, både traditionella och "nya".

En bred syn på functional food gör också den svenska översättningen mindre kontroversiell. Ett grundproblem med begrepp som mervärdesmat och ännu mer med nyttomat - för en liten, exklusiv grupp av speciella livsmedel, är nämligen hur man skall kunna undvika att de nya produkterna framstår som väsensskilda från vanlig nyttig mat. Egenåtgärdsprogrammet ställer krav på att hälsopåståenden skall göras mot bakgrund av och i sammanhang med en allmänt näringsriktig kost. Beträffande produktspecifika fysiologiska påståenden (PFP) ställs kravet att produkten, utöver $\sin$ speciella och dokumenterade effekt, genom sin sammansättning skall bidra till att kosten blir näringsriktig. Den grundläggande principen bakom dessa krav är viktig att framhålla - att functional foods är vanliga livsmedel som passar in i och bidrar till en näringsriktig kost, utöver sina speciella extra effekter. En bred syn på mervärdesmat/nyttomat/functional food skulle stimulera till att kommunicera mervärdena - både traditionella och "nya" dokumenterade - på ett balanserat sätt mot bakgrunden av en allmänt näringsriktig kost.

Egenåtgärdsprogrammet "Hälsopåståenden i märkning och marknadsföring av livsmedel" har inte heller definierat functional foods. Styrgruppen har valt att $\mathrm{i}$ det nya till PFP utvidgade programmet tala om "Livsmedel med hälsopåståenden". Enligt det ursprungliga programmet från 1990 kan man göra allmänna på ståenden i två steg kring något av de åtta etablerade kost-hälsa sambanden. Det krävs då att produkten uppfyller vissa krav vad gäller innehåll av näringsämnen eller kostfiber. Dessutom skall det vara produkter som normalt äts i mängder som väsentligt påverkar kostens sammansättning. Däremot krävs inga vetenskapliga effektstudier, eftersom påståendena rör väl etablerade samband. Näringsfysiologisk a påståenden, dvs uppgifter om väl etablerade nor- 
mala funktioner av näringsämnen får också göras. Kravet är då att produkten skall innehålla näringsämnet ifråga i riklig mängd.

Produktspecifika fysiologisk a påståenden, PFP, kräver vetenskaplig dokumentation av produktens effekt. Dokumentationen skall vara granskad innan produkten sätts på marknaden med påståendet. Kraven är höga - effekten skall ha visats i studier på människa. Detta kommer därför att under överskådlig tid förbli en relativt liten och exklusiv grupp produkter - låt oss tills vidare kalla dem för PFP-produkter. Produkterna kommer att kännas igen genom en text med speciell logotyp som anger att produktens dokumentation granskats enligt livsmedelsbranschens regler för hälsopåståenden.

Frukt och grönt. Livsmedelsverket fick i regleringsbrevet för 2001 uppdraget "att i samarbete med berörda expertorgan utarbeta förslag till reglering av märkning för produktgruppen fruktgrönsaker-fullkornscerealie $r$ i relation till hjärtkärlsjukdomar och cancer, eventuellt inom ramen för den befintliga principen för symbolmärkning." Uppdraget redovisas i en promemoria 2001-12-21 . Slutsatsen är att "Livsmedelsverket avstår från att föreslå regler för märkning av frukt-gröntfullkornscerealier. Samtidigt önskar verket stöd för det långsiktiga arbetet för att på ett effektivt sätt öka befolkningens intag av nämnda livsmedel." I promemorian hänvisar verket upprepade gånger till egenåtgärdsprogrammet och SNF, som flera gånger på senare år väckt frågan om att utöka egenåtgärdsprogrammet till allmänna hälsopåståenden också för frukt och grönt. Problemet är att dessa inte kan konstrueras enligt tvåstegsprincipen. Det beror på att en skyddande effekt av frukt och grönt mot hjärtkärlsjukdomar och vissa former av cancer bygger på enbart epidemiologisk a samband. Vi kan inte $\mathrm{i}$ analogi med de övriga tvåstegspåståendena relatera den skyddande effekten till någon viss definierad och mätbar komponent. Ett annat hinder har varit att myndigheterna vid revideringen 1996 explicit förbjöd påståenden kring kost och cancer. De epidemiologiska sambanden mellan frukt och grönt och sjukdomsrisk är starka och tillförlitliga. Tillsammans med övriga näringsmässiga fördelar, har de ansetts tillräckliga som grund för rekommendationen att äta $1 / 2 \mathrm{~kg}$ frukt och grönt/dag.

Fullkornsprodukter och minskad risk för hjärtkärlsjukdom bygger på epidemiologiska studier av nyare datum. Det råder konsensus kring att vissa lösliga gelbildande fibertyper, främst från havre, kan bidra till att sänka kolesterolvärdet och därmed till att minska risken för hjärt-kärlsjukdomar. Allmänna hälsopåståenden utifrån dessa samband är tillåtna både i Sverige och i USA. Men lösliga fibrer förklarar inte de epidemiologiska sambanden mellan intag av fullkornsprodukter och minskad risk för hjärt-kärlsjukdom. Sambandet syns i många studier med helt olika nivåer och typer av kostfiber, men kan inte förklaras utifrån kända och mätbara komponenter och deras fysiologiska effekter. De behöver värderas utifrån svenska förhållanden.

Det är angeläget att nu ta fram riktlinjer för att i marknadsföringen kommunicera fördelar med frukt och grönt respektive fullkorn till konsument. Sådana riktlinjer behövs inte minst i "arbetet för att på ett effektivt sätt öka befolkningens intag av nämnda livsmedel", speciellt eftersom Livsmedelsverket förordar samarbete mellan myndighet, institutioner och branschorgan. Livsmedelsverket är emellertid bakbundet av EU-arbetet med hälsopåståenden, men också av det faktum att verkets ansvar i detta sammanhang är begränsat till märkning, dvs det som står på förpackningen. När det gäller marknadsföring av ett helt sortiment som frukt och grönt, vars produkter sällan är förpackade, är broschyrer, annonser och internet viktigare kanaler. Egenåtgärdsprogrammet gäller all marknadsföring, och skall därför beakta helhetsbilden av all kommunikation med hälsopåståenden i marknadsföringen. Frågan om hälsopåståenden för frukt/grönt och fullkorn bör tas upp med hög prioritet inom egenåtgärdsprogrammet.

\section{References}

1. Palm H. Mervärdesmat - en funktionell term. Scand $\mathbf{J}$ Nutr 2001;45:97-104.

2. Hadenius P: Det skall vara svenskt och enkelt. Forskning och Framsteg 2002;1:37-9.

3. Diplock AT, Aggett PJ, Ashwell M et al: Scientific concepts of functional foods in Europe: consensus document. Br J Nutr 1999;81(Suppl 1):S1-27.

4. www.snf.ideon.se

Nils-Georg Asp

SNF Swedish Nutrition Foundation, Ideon, SE-223 70 Lund, Sweden 